\title{
THE FORM OF ORDINARY TESTAMENTS UNDER CHINESE AND RUSSIAN LAW AND IN THE EUROPEAN LEGAL TRADITION
}

\author{
JAROSŁAW TURŁUKOWSKI, \\ University of Warsaw (Warsaw, Poland)
}

https://doi.org/10.21684/2412-2343-2020-7-3-136-165

This paper analyses regulations concerning ordinary forms of testament in Russian and Chinese legislation against the background of selected solutions specific for particular European legal systems. It begins with a brief analysis of the development of Chinese and Russian civil law. This is intended to show the differences, but also the similarities, between them, caused, among other things, by the influence of Soviet law as well as ongoing reforms of succession law in both countries. Such similarities justify the need for a comparative examination of these legal orders, while the European context makes it possible to highlight their specific features. Taking into account the aim of this study, particular attention is paid to the normative sources of inheritance law and the traditional division of testaments into ordinary and special wills, something which is a common feature of Russian law, Chinese law and European legal traditions. The paper then examines particular forms of wills commonly found in European legislation, and follows this with a discussion of whether such solutions exist in Chinese and Russian law. Forms of holographic and notarial wills are presented in this manner. Particular attention is paid to forms of wills that occur only in one legal order, e.g. printed testaments as well as video and audio testaments in Chinese law, as well as the several types of notarial wills in Russian law. The paper concludes with a discussion of Russian and Chinese legislation's various approaches to preserving the genuine will of the testator and the security of the legal transaction.

Keywords: ordinary testaments; Chinese law; Russian law; holographic will; notarial will; printed will; video will.

Recommended citation: Jarosław Turłukowski, The Form of Ordinary Testaments Under Chinese and Russian Law and in the European Legal Tradition, 7(3) BRICS Law Journal 136-165 (2020). 


\section{Table of Contents}

\section{Introduction}

\section{The Main Sources of Modern Chinese and Russian Succession Law \\ 2. Ordinary and Special Wills in Chinese and Russian Law \\ 3. Testamentum Holographum \\ 4. Notarial Wills \\ 5. Printed Wills in Chinese Law \\ 6. Video Testaments and Audio Testaments in Chinese Law In Lieu of Conclusions}

\section{Introduction}

To begin with, a few words must be said as to why one would compare modern Russian and Chinese law. It is clear that, since ancient times, China and Russia have developed in different directions, so, until the $20^{\text {th }}$ century, it is difficult to speak of any common legal roots. It seems valid to conclude that, throughout the $19^{\text {th }}$ century, both the Russian Empire and the Middle Kingdom maintained their legal systems based on local traditions, often with feudal elements. This does not negate the fact that there was preparatory work undertaken to reform statutes with the aim of grounding them primarily in Western legislation. As pointed out by M. Łągiewska, as early as in

the late reign of the Qing dynasty (1902), a special codification commission was set up by the government ... which was intended to revise the existing provisions, taking as its starting point the solutions adopted in Western legal systems.

Similarly, in tsarist Russia, from 1882 onwards, work took place in the Ministry of Justice to review existing civil laws and to create a draft of a civil code. ${ }^{2}$ It should be emphasised that the draft of the Civil Code of the Russian Empire (original name: Grazhdanskoe Ulozhenie) contained not only the text of the future code, but also a host of comments and justifications for practically every article. Virtually all of the relevant European legal codifications known at the time were referred to in the text.

\footnotetext{
Magdalena Łągiewska, Charakterystyka chińskiego prawa cywilnego - wybrane aspekty [Characteristics of Chinese Civil Law: Selected Aspects], 12 Gdańskie Studia Azji Wschodniej [Gdansk Journal of East Asian Studies] 86 (2017).

2 For more on this topic see Гуляев А.М. Единство гражданского права и проект Гражданского уложения [Alexey M. Gulyaev, The Unity of Civil Law and the Draft Civil Code] 14-15 (Kiev: Printing House of I.N. Kushnerev and Co., 1903).
} 
This draft law, with such justifications (which appear to be a compendium of the highest quality containing civil knowledge of a comparative legal nature), was a great achievement for Russian civil law, as domestic law had undergone comprehensive analysis in the context of foreign legislation.

This common trend, or codification path, diverged in China and Russia. Unfortunately, the Russian Empire did not manage to complete its legislative reform, as the process of slow, evolutionary codification was brutally interrupted by the revolutionary events of 1917. In contrast, the fate of codification bills in China was much more fortunate, as the country's specific reception of Western law (with some Japanese influence), and particularly German legislation, led to the adoption of a number of legal acts during the period of the Republic of China. With regard to the purpose of this study, the Civil Code of the Republic of China that was adopted in 1929 should be seen as the second most important after the Constitution. ${ }^{3}$ However, the term "Civil Code of 1929," which can be encountered in Polish literature on the subject, is an oversimplification, as particular parts of the Code entered into force at different times. The Civil Code of the Republic of China consisted of five books containing 1,225 articles. Book I"General Principles" entered into force on 10 October 1929, while book II "Obligations" and book III "Rights over Possessions" entered into force on 5 May 1930, and book IV "Family" and book V "Succession" became law on 5 May 1931. ${ }^{4}$ Additionally, it should be noted that the Civil Code of the Republic of China cannot be considered an accomplishment solely of the Republic of China, since, as pointed out by Wang Zhihua,

[In] 1911, the draft of the civil code of the Qing dynasty was made public. After overthrowing the Qing dynasty, the draft of the Code was amended in 1925 and then adopted as the Civil Code of the Republic of China in the years $1929-1931 .^{5}$

Paradoxically, even though (unlike Russia under the communist regime after 1917) China had eradicated the remains of the monarchist-feudal regime and embarked upon, one might have thought, the path to developing a market economy, this situation changed radically after the proclamation of the People's Republic of China on 1 October 1949.

\footnotetext{
Cf. Łągiewska 2017, at 87.

4 Чжихуа В. Революции и кодификация китайского гражданского законодательства // Вестник Санкт-Петербургского университета. Право. 2018. Т. 9. Вып. 3. С. 424 [Wang Zhihua, Chinese Revolutions and Codification of Chinese Civil Legislation, 9(3) Bulletin of St. Petersburg University. Law 422, 424 (2018)].

5 Id. at 424. In this paper Professor Zhihua (p. 425), in reference to Shuai Tianlong, claims that the Company Law of the Qing dynasty, adopted in 1904, was the first modern code in Chinese history.
} 
At that time, the existing legislative acts, the so-called "Six Codes" of the Kuomintang, were repealed, as they did not reflect the objectives of Marxism Leninism. ${ }^{6}$

More similarities with Soviet Russia can be found since China's communist authorities, just like Russia's communists, sought to abolish the previous legal system immediately and without undue delay, without seeking to achieve any evolutionary process, even towards a Marxist approach. As indicated by B. Wiśniewski, in fact:

[T]his process began in January 1949, when the Communist Party of China (CPC) announced the launch of another series of talks with the nationalists, in which it demanded the Constitution and all laws adopted during the nationalist government be declared void. One month later, the Central Committee of the CPC issued a directive concerning the abolition of the republican codes and the establishment of a discretionary judicial power to handle outstanding issues. This act derogated all laws and regulations adopted by the government of the Republic of China, including the Civil Code of the Republic of China.

It seems, however, that the Soviet authorities were characterised by greater passion for legislation, since they tried to dress up their revolutionary ideas in the form of decrees, even though it was really only about abolishing inheritance as a phenomenon. ${ }^{8}$ In other words, the year 1949 in China might be compared to the year 1918 in Soviet Russia. I therefore believe that this common experience of radically discontinuing earlier legislation, and even the form of the legal system, is one of the reasons why it is worth comparing Chinese law with Russian law. There is no doubt that, at certain stages, both China and Russia have had a very similar history of implementing socialist solutions in legislation.

Of course, by adopting such a point of view it is possible to compare any socialist or post-socialist legal system, such as those in Cuba or Vietnam, but there is one more thing that should be noted. After Mao Zedong initially came to power, the reforms in China were undoubtedly partly modelled on Soviet law. One may encounter the view that even "current Chinese legislation is a mixture of native, western and Soviet ideas."

6 Cf. Łągiewska 2017, at 88.

7 Bartosz Wiśniewski in Grzegorz Lebedowicz et al., Zarys chińskiego prawa cywilnego w dobie kodyfikacji [An Overview of Chinese Civil Law in the Era of Codification] 61 (Toruń: Adam Marszałek, 2019).

8 Декрет об отмене наследования от 27 апреля 1918 г. // Исторический факультет МГУ [Decree Abolishing Succession of 27 April 1918, Faculty of History, Moscow State University] (Jul. 2, 2020), available at http://www.hist.msu.ru/ER/Etext/DEKRET/18-04-27.htm.

9 Grzegorz Lebedowicz in Lebedowicz et al. 2019, at 10. 
At the same time, it would be a misconception to believe that in China a wholesale adoption of Soviet law took place. One should perhaps instead speak of China taking on certain models and adopting certain doctrine-related postulates. For instance, China's so-called "economic theory" is taken from Soviet legal doctrine concerning how contracts were to be concluded with regard to economic matters..$^{10}$ In addition, one observes the use of the term "citizen" to describe a natural person, just as in Soviet legislation and partly in the laws enacted in post-Soviet regions." Similar examples abound when analysing individual sections of Chinese legislation. In turn, Russia's legal doctrine continues to be based not only on the achievements of the $19^{\text {th }}$-century "silver" period of Russian doctrine, but also on the Soviet legacy, which has partially retained its importance. It does not matter that in 1991 in Russia, unlike in China, there took place a formal discontinuation of the Soviet system, which ceased to exist. Both the Chinese and Russian legal systems are, to a varying extent, based on the idea of a market economy and accept Western patterns, while at the same time combining them with local legal tradition and culture. Moreover, there is also no doubt that China's post-Confucian culture differs from Russian culture.

For the reasons set out above, it seems justified not only to perform a general analysis of the legal systems of Russia and China, but also to carry out a comparative analysis of various institutions, in particular those relating to the law of succession. Another reason is the fact that both China and Russia should be considered systems of continental law, though with significant differences from the laws of European countries. Certain differences, when compared with the legal solutions in European countries, call for an examination of Chinese and Russian provisions in the context of European legal traditions. As far as the European legal tradition is concerned, its Roman roots can, of course, be used to demonstrate the shared solutions and structures. However, modern legislation in European countries often differs from Roman law, naturally, but - most importantly - modern European legislation also differs considerably between individual states. This is particularly evident when one compares various civil law institutions that are generally known to the legislation of each European country. In other words, when carrying out a more detailed civil law analysis it is more difficult to speak of a uniform European legal tradition. In this context, the Polish legal system is interesting, as it not only came under the direct influence of some of the most important European legal traditions, but, in fact, it can be considered a jurisdiction which was historically-speaking formed as a combination of elements from several different legal systems while at the same

10 Cf. Bartosz Wiśniewski in Lebedowicz et al. 2019, at 66.

11 For example $c f$. Article 1 of the Law of Succession of the People's Republic of China. English version from "Laws and Regulations of the People's Republic of China Governing Foreign-Related Matters (1991.7)" (Jul. 2, 2020), available at https://baike.baidu.com/item/\%E4\%B8\%AD\%E5\%8D\%8E\%E4\%B A\%BA\%E6\%B0\%91\%E5\%85\%B1\%E5\%92\%8C\%E5\%9B\%BD\%E7\%BB\%A7\%E6\%89\%BF\%E6\%B3\%95 /336055?fromtitle=\%E7\%BB\%A7\%E6\%89\%BF\%E6\%B3\%95\&fromid=10599415\&fr=aladdin. 
time preserving local elements. This situation is the outcome of Poland's declaration of independence in 1918, after over 100 years of not being a sovereign state. At that time, Poland was made up of various territories that had earlier belonged to various empires with a variety of legal systems. The newly born state inherited a civil law tradition based on the BGB, ABGB, Napoleonic Code and the Digest of Laws of the Russian Empire. This may not be the correct conclusion for each legal institution, but as the result of the creative combination of different legal traditions, the Polish legal order, or more accurately the legislative system, can be considered to be a national average of European traditions. This will certainly be relevant with regard to the forms of wills enshrined in Polish law, something which may be representative when it comes to the European continental tradition concerning forms of testaments. For the reasons described above, when analysing Chinese and Russian law one might also highlight selected solutions encountered in Polish law as an example of the European legal order.

\section{The Main Sources of Modern Chinese and Russian Succession Law}

Russian and Chinese succession laws are at a slightly different stage of development from, for example, a formal point of view. With regard to the Russian Federation, after the collapse of the Soviet Union a far-reaching reform of civil law was achieved, culminating in the adoption of a modern civil code, which replaced the civil code that had come into force in the communist period. Adoption of the third part of the Civil Code of the Russian Federation, which became effective on 1 March 2002, is the most important in regard to regulating the succession process. ${ }^{12}$ Russian Inheritance Law has a certain positive feature, namely the fact that most of the regulations on succession law are laid down directly in the civil code, which facilitates understanding succession-related matters. Inheritance law is often seen as a fairly conservative and stable domain, generally resistant to change. Moreover, Soviet inheritance law, be it in the first or second Civil Code of the Russian Soviet Federated Socialist Republic, did not tend to change much. Extensive reforms of inheritance law were rare. Therefore, the adoption of the third part containing Chapter V on inheritance law could have stabilised the succession process for years. However, in the last few years, Russian succession law has witnessed an attempt at a rather bold reform, one which consists in the introduction of institutions previously unknown to Russian legislation. I am referring here to Federal Law No. 259-FZ, which entered into force on 1 September 2018 , and which in regard to succession introduced the institution of foundation

12 Гражданский кодекс Российской Федерации (часть третья) от 26 ноября 2001 г. № 146-Ф3 // СПС «КонсультантПлюс» [Civil Code of the Russian Federation (Part Three) of 26 November 2001 No. 146-FZ, SPS "ConsultantPlus"] (Jul. 2, 2020), available at http://www.consultant.ru/document/ cons_doc_LAW_34154/. 
into the Russian legal order. In addition, Federal Law No. 217-FZ, which entered into force on 1 June 2019, should be mentioned, as it introduced a succession agreement as well as a joint will (for married couples), i.e. a legal structure that previously had been know merely as a doctrinaire concept. Given such a state of affairs, it cannot be concluded that there has been a period of stability in Russian succession law, since Russian legislators are still making fundamental changes to it.

The state of succession law in China is slightly different. First of all, it should be pointed out that China is currently in the process of implementing a new civil code which is not being adopted as a single act. Among other things, the Civil Code of the Russian Federation was also passed in parts and not as a single act on one day. As of 1 October 2017, the General Provisions of Civil Law of 15 March 2017 apply in China. ${ }^{13}$ In non-Chinese foreign-language legal literature (e.g. in English, Russian and Polish language literature on the subject), there exist different translations of this legal act. The following translations of the title are used in particular:"The General Provisions of Civil Law of the People's Republic of China," and "The General Rules of the Civil Law of the People's Republic of China.."14 Despite the differences in terminology, it is clear that this is the first part of the Chinese Civil Code, which is merely the beginning of the new codification. As Wang Haijun points out,

[The] adoption of the law "General Provisions of Civil Law of the PRC" marks an important event in the history of Chinese civil legislation, and it is the first step in drafting the Civil Code of the PRC, which will allow the Chinese civil law system to officially enter the "age of the Civil Code."15

Although the concept itself of entering the age of the Civil Code is somewhat questionable, not least because of the adoption of a Civil Code by the Republic of China in 1929, as has already been mentioned earlier, it clearly shows that this is a single legislative process reflecting a desire to develop a greater legislative work. As the title itself suggests, apart from a number of articles, the law of 15 March 2017 does not regulate the succession process. Nevertheless, the relatively few provisions relating to succession law are extremely important in terms of legal construct. There

13 中华人民共和国民法总则 [General Provisions of Civil Law of the People's Republic of China] (Jul. 2， 2020), available at http://www.npc.gov.cn/zgrdw/npc/xinwen/2017-03/15/content_2018907.htm.

14 For more on this subject cf. Ербахаев E.А. Новые Основные положения гражданского права Китайской Народной Республики // Вестник СПбГУ. Право. 2019. Т. 10. Вып. 2. С. 390-391 [Evgeny A. Erbakhaev, New Principal Provisions of Civil Law in the People's Republic of China, 10(2) Bulletin of St. Petersburg University. Law 390, 390-391 (2019)]; Igor Szpotakowski in Lebedowicz et al. 2019, at 106-107.

15 Хайцзюнь В. Закон «Общая часть гражданского права КНР» и развитие гражданского права Китая // Вестник Санкт-Петербургского университета. Право. 2018. Т. 9. № 3. С. 414 [Wang Haijun, The General Principles of Civil Law and the Development of Chinese Civil Law, 9(3) Bulletin of St. Petersburg University. Law 413, 414 (2018)]. 
are regulations that can be seen as general principles of succession law, as well as rules that shape the structure of Chinese inheritance law at its basic level. Such a quasi-constitutional regulation, which is of particular importance to a socialist society with a market economy, stems from Article 124, which states that

a natural person shall have the right to inheritance in accordance with law. The legitimate private property of a natural person may be inherited according to law. ${ }^{16}$

In turn, Article 16 of this legislation, according to which in the "case of inheritance or reception of donations, etc. that involves the protection of the interests of a fetus, the fetus shall be deemed as having the capacity for civil-law right. However, such capacity shall be deemed non-existent $a b$ initio if the fetus is stillborn at the time of delivery," we see legislation of structural importance. ${ }^{17}$ As noted by E. Erbakhaev, this is one of the most progressive new changes, as not only are the non-material rights of embryos protected, but so too are their material rights and interests. ${ }^{18}$ According to Erbakhaev, this is a development of the principle of protecting the interests of children, who were conceived at the time the bequeather was alive, as was already expressed in Article 28 of the Law of Succession of the People's Republic of China of 10 April 1985. At the same time, it is possible to point to contradictory statements in Chinese doctrine regarding this issue. According to Wang Haijun, an embryo is not a natural person in a legal sense and thus has no legal capacity, but at the same time embryos "can become heirs of property or receive a monetary gift and should be considered civil law entities." ${ }^{\prime 1}$ It seems that if someone is considered an entity, it should also be recognised that they have at least partial legal capacity (this does not mean capacity to perform acts under the law). Moreover, Article 16 itself requires that embryos shall be considered to have legal capacity (at least within the stated scope).

Similar solutions can be found in Russian law, as pursuant to Article 1116 of the Russian Federation Civil Code,

[T]hose left alive as of the date of opening of the inheritance and also persons conceived during the lifetime of the deceased and born after the opening of the inheritance can be called upon to inherit ... ${ }^{20}$

\footnotetext{
16 English language version of the General Provisions of Civil Law of the People's Republic of China available at http://www.npc.gov.cn/englishnpc/lawsoftheprc/202001/c983fc8d3782438fa775a9d67d6e82d8. shtml.

17 Id.

18 Erbakhaev 2019, at 394.

19 Haijun 2018, at 415.

20 Civil Code of the Russian Federation (Part Three), supra note 12.
} 
At the time of writing, the Law of Succession of the People's Republic of China, ${ }^{21}$ adopted at the Third Session of the Six National People's Congress and promulgated by Order No. 24 of the President of the People's Republic of China on 10 April 1985, and effective as of 1 October 1985, was still in force. As noted by Erbakhaev, this law has not been amended since the time of its adoption. ${ }^{22}$ The final version of a new inheritance law, which should have been adopted in March 2020, has already been published. ${ }^{23}$ However, the passing of this law was deferred due to the COVID-19 pandemic (hereinafter, the Draft Inheritance Law shall be abbreviated as DIL). Such a deferral seems to be of a technical nature and the adoption of the DIL is a foregone conclusion. Taking into account the objectives of this study, as far as Chinese law is concerned, I will examine the provisions regarding the form of wills mainly in the context of this legal act.

\section{Ordinary and Special Wills in Chinese and Russian Law}

Both Chinese and Russian law make a distinction between ordinary wills and special wills, as is typical for continental legislation. No additional evidence or circumstances justifying the establishment of a testament are needed in order to draw up an ordinary will. As can be inferred from the name itself, special wills are not intended for times when the testator has normal living circumstances and would merely like to dispose of his assets in the event of his death.

Whenever the law establishes specific form requirements there will be situations where it is difficult, or even impossible, for a testator to comply: witnesses, or a notary, may not be available, and sometimes even a holograph will cannot be made. ${ }^{24}$

In actual fact, Russian legislation provides for one dominant form of will a notarial act. This form of testament should, undoubtedly, be considered an ordinary

21 Law of Succession of the People's Republic of China, supra note 11.

22 Ербахаев Е.А. Наследование в КНР: общие положения // Евразийская парадигма России и трансформация политико-правовых институтов стран Азиатско-Тихоокеанского региона: материалы V Международной науч.-практ. конф. (Улан-Удэ, 19-21 июня 2014 г.) [Evgeny A. Erbakhaev, General Provisions of Chinese Inheritance Law in Eurasian Paradigm of Russia and the Transformation of Political and Legal Institutions in the Countries of the Asia-Pacific Region: Materials of the $5^{\text {th }}$ International Scientific and Practical Conference (Ulan-Ude, 19-21 June 2014)] 145 (Yu.I. Skuratov (ed.), Ulan-Ude: Publishing House of the Buryat State University, 2014).

23 民法典分编 (草案) 第四、五编——婚姻家庭编、继承编 (Jul. 2, 2020), available at https://www. jianshu.com/p/59fee04503b2?utm_campaign=maleskine. At first, the fourth part "Marriage. Family" was published. Legal and inheritance matters are set out in the fifth part, while the third chapter is devoted to inheritance via wills and to legacies.

24 Comparative Succession Law. Vol. I: Testamentary Formalities 451 (K.G.C. Reid et al. (eds.), Oxford: Oxford University Press, 2011). 
will. However, a more comprehensive analysis does not allow one to conclude that Russian law provides for a uniform structure of notarial will, as is the case, for example, in Polish law. In accordance with Article 950 of the Polish Civil Code, a "will may be drawn up in the form of a notarial act." Polish law does not provide for any particular variety or types of notarial will. Furthermore, none of the special testaments can be considered a variant of a notarial will. In Russian law, there is no doubt that a classic notarial will may be drawn up, i.e. a document whose form is often referred to as "open notarial will."25 Part 1 of Article 1125 of the Russian Federation Civil Code states that in the case of a single testator, i.e. in a typical situation which does not involve a joint testament of two spouses,

a will attested by a notary shall be signed by the testator or written by a notary in the testator's words.... Technical facilities can be used to write or record a will (computer, typewriter etc.). ${ }^{26}$

Furthermore, the second ordinary form of will is, in fact, the so-called "closed will," which is a variant of a notarial act. According to part 1 of Article 1126 of the Russian Federation Civil Code,

The testator shall be entitled to create a will without providing other persons, including a notary, with the chance of familiarising himself with the content thereof (a closed will).

A testament drawn up in this way is to be forwarded to a notary for further action and safekeeping. In addition, Russian law provides for a number of forms of will, such as military wills or the wills of persons in prison, which could at first sight be considered special wills. However, on closer examination, it is clear that we are dealing here with substitutes of a notarial act, where instead of a notary there are other authorised persons, for example, the captain of a vessel, the commander of a military unit, etc. Moreover, Article 1127 of the Russian Federation Civil Code, which lists such forms of wills, indicates that such testaments shall "qualify as wills attested by a notary." This perhaps is too far-reaching a thesis, but these are ordinary forms of wills that can be drawn up under specific conditions when access to a notary may be difficult (although not always impossible). The possibility of drawing up such a testament is not linked to any risk to life or health, and special conditions (e.g. being on board a ship) are not to be considered an emergency situation. Russian law regulates only one form of special will in the strict sense of the word. Part 1 of Article 1129 of the Russian Federation Civil Code states:

\footnotetext{
25 Cf. Id. at 449.

26 Civil Code of the Russian Federation (Part Three), supra note 12.
} 
A citizen who is in a situation that obviously threatens his life and who, by virtue of prevailing extraordinary circumstances, is deprived of an opportunity to create a will under the rules of Articles 1124-1128 of the present Code may make his last wishes as to the disposition of his property in a simple written form. The citizen's last wishes set out in simple written form shall be deemed his will, if the testator has written a document in his own hand in the presence of two witnesses the content whereof evidences that it is a will.

Unlike Russian law, Chinese legislation does not enshrine the dominance of the notarial form of wills. Article 913 of the DIL provides for the possibility of drawing up a handwritten or otherwise holographic testament. ${ }^{27}$ The use of such a form does not seem to be subject to additional considerations, so it must be concluded that this is a form of ordinary will. This approach by Chinese legislators is almost identical to that which is found in many European legal systems. Under Chinese law, drawing up a "classical" holographic will does not require witnesses. It is only when the testator, due to physical limitations, is not able to draw up the text of the testament on his own that two witnesses are necessary (cf. Art. 914 of the DIL). In my opinion, this cannot be considered a separate form of will, but more a qualified case of drawing up a handwritten will. It is Article 915 of the DIL that provides for the possibility of drawing up a printed testament, which also requires the presence of no less than two witnesses. This can be deemed a separate form of ordinary testament, i.e. a printed will. The fact that Chinese law allows for the creation of an audio/video testament deserves particular attention. The vast majority of legal systems in the world (like those in the European Union) do not provide for such a possibility, nor do any proposals exist for introducing such a form of will, although preliminary drafts (including academic proposals) have started to emerge. ${ }^{28}$ In the case of Chinese legislators, it does not seem to be an accidental provision or a new trend, since a regulation regarding audio wills (though not video ones) can already be found in the Law of Succession of the People's Republic of China, of 10 April $1985 .{ }^{29}$ Article 17 of that Act provides that,

A will made in the form of a sound recording shall be witnessed by two or more witnesses.

This only concerned sound recordings, because in the 1980s image reproduction technology was not as available as it is today. As has been pointed out by E. Erbakhaev,

27 Supra note 23.

28 For a more comprehensive discussion see Mariusz Załucki, Videotestament. Prawo spadkowe wobec nowych technologii [The Videotestament: Inheritance Law in the Context of New Technologies] 119 (Warszawa: C.H. Beck, 2018).

29 Law of Succession of the People's Republic of China, supra note 11. 
the audio form of a will is one of the three ordinary forms of will, alongside a notarial (public) will and a handwritten one. Audio wills are classified as a closed (home) form of will. ${ }^{30}$ Taking into account technological developments, Article 916 of the DIL provides for drawing up testaments in the form of either an audio or video recording. Of course, under the regulations of the DIL, this remains a form of ordinary will. In concluding the list of normal forms of will, one should mention the possibility of drawing up a notarial will, "in notarial organizations," jointly by two notaries (Art. 918 of the DIL). Unlike Russian law, Chinese legislation does not provide for substitutes to notarial wills. Besides that, it cannot be said that this form of will has any dominance in Chinese legislation. Accordingly, the matter of applying, or not applying, the regulations regarding notarial wills to other forms of ordinary testaments does not arise.

Apart from that, Chinese law in the articles of the DIL regulates one form of special will, namely an oral testament requiring the presence of no fewer than two witnesses.

\section{Testamentum Holographum}

In certain Member States of the European Union (and especially in Polish inheritance law), holographic wills (otherwise known as those handwritten by the testator) are adjudged to be forms of ordinary wills. As noted by M. Kuryłowicz, their name comes from the Greek testamentum holographum, which means "to write in full without abridging" or "to write completely." Originally, this term did not stand for a handwritten testament in the proper meaning of the words, although the practice of writing a will and passing it to a notary for approval was known. The term "holographic testament" was present in Roman law as far back as the $5^{\text {th }}$ century A.D. ${ }^{31}$

A handwritten testament may be regarded as one of the oldest forms of testament to have survived to the present day, retaining its characteristic traits. Above all, one of its traits is that it is written down by hand. This simplest form of will is regulated in Poland by section 1 of Article 949 of the Polish Civil Code, according to which the testator should write it in full, by hand, then sign it and put the date on it. There is also the unconditional requirement to write the entire will by hand and to sign it, viz. it is not possible to write such a document on a computer, print it and sign the printed text. In essence, even a few printed words will render the will invalid. At the same time, Polish law treats the absence of the date on a testament quite liberally, so it does not per se lead to the will being nullified. From section 2 of Article 949 of the Polish Civil Code it can be concluded that the absence of a date does not invalidate a handwritten will should it not raise any doubts as to: the capacity of the testator to draw up the will, the content of the will, or to the mutual relationship between multiple wills. In other words, an undated holographic testament can only

\footnotetext{
30 Erbakhaev 2014, at 145.

31 Marek Kuryłowicz, Testamentum holographum, 13(10) Rejent [Notary] 119, 120-121 (2003).
} 
be considered invalid if the lack of date does not allow it to be determined that the testator was of sound mind at the time the testament was drawn up. It might also occur that there are two undated wills with mutually exclusive content, and there is no possibility to determine which one was drawn up first. This lack of date results in the nullity of both of the wills.

Although the concept of a holographic will exists in most European countries, there are differences in the formal requirements laid down in different legal systems. Neither Soviet law nor that of most countries referred to as post-socialist was familiar with this form of will. On the other hand, the Civil Code of the Russian Federation, in Article 1129, only allows a "simple written form" to be retained in exceptional circumstances should the testator find himself in circumstances which clearly threaten his life, as well as when due to exceptional circumstances he is deprived of the possibility of drawing up a notarial form of will. In this context, the notarial form of will should be understood as a rather broad category. It is not possible to draw up a classical notarial act or to use a so-called closed testament that is then handed over to a notary. In addition, the testator may not draw up a testament in a form that is equated with a notarial act, i.e. in a so-called quasi-notarial form, for instance a testament drawn up on board a vessel. It should also be stressed that the testator should write the testament with his own hand and sign it in the presence of two witnesses. Such requirements are excessively restrictive, as a bequeather in adverse circumstances may not be able to call for witnesses, or the persons present may not be aware that the testator is writing a testament as, for example, they may be preoccupied with saving the testator's life. Such an approach by Russian legislators seems disproportionate, as some European countries (which allow the form of a handwritten will as an ordinary testament) have less demanding requirements. In most situations, the characteristics of the testator's handwriting, which can be examined after his death, are the best guarantee of the authenticity of the will. However, the position of Russia's legislators is clearly expressed in paragraph 2 of item 1 of Article 1129 of the Civil Code:

The citizen's last wishes set out in simple written form shall be deemed his will, if the testator has written a document in his own hand in the presence [emphasis added] of two witnesses the content whereof evidences that it is a will.

One should also compliment Russian legislators on one more issue, namely that there is no requirement to title the will, as it suffices that the content indicates that it is a declaration in the event of one's death. Despite the necessity for witnesses, the Russian statute books are of the view that one is not obliged to sign one's testament or insert a phrase such as "I hereby certify." It is also of no relevance if, at the time the will is read, none of the witnesses is alive, since at the time the testament was drawn 
up, the requirement of presence was formally met. ${ }^{32}$ At the same time, there are opinions that, even in the case of a testament drawn up under special circumstances, the regulations in part 4 of Article 1125 of the Civil Code of the Russian Federation should be applied per analogiam. ${ }^{33}$ Although this Article concerns the form of a notary will, part 4 provides that:

A witness can be in attendance when a will is drawn up and attested by a notary if the testator so wishes. If a will is drawn up and attested with a witness in attendance it shall be signed by the witness [emphasis added] and it shall bear an indication of the full name and residential address of the witness in compliance with the witness's personal identity document.

This approach would not seem to be the right one, as it applies to a situation where witnesses are present at the request of the testator. This situation has nothing to do with the mandatory presence of witnesses when drawing up a special form of a testament. However, such views, though they may be contested, express the general trend in Russian inheritance law, in which a notarial act is the primary form of will, while other forms are merely a variety of it or acceptable substitutes. Unfortunately, this notion applies even to special wills, although there is no substantive basis for this. Moreover, there is some doubt as to which analogies should be applied analogia iuris or the analogia legis.

Although I have previously stated that Russian law does not provide for a classical form of holographic will as a separate form of ordinary will, one that does not require the participation of witnesses or notaries, such a statement should be supplemented with mention of so-called closed notarial wills. In the European tradition:

A "closed" will is a private document which, nonetheless, is presented to a notary for authentication and, often, for safe keeping as well. The will can, but need not, be the holograph of the testator, but if it is not, some countries require that the testator sign on each page as well as at the end, and that the pages be numbered. ${ }^{34}$

A similar form of testament is provided for in Russian law. Part 1 of Article 1126 of the Russian Federation Civil Code sets out that,

32 Тычинин С.В. в: Комментарий к гражданскому кодексу Российской Федерации. Часть третья (постатейный) [Sergey V. Tychinin in Commentary on the Civil Code of the Russian Federation. Part Three (Item-by-Item)] 82 (A.P. Sergeev (ed.), $2^{\text {nd }}$ ed., Moscow: Prospekt, 2016).

33 See, е.g., Петров Е.Ю. в: Наследственное право: постатейный комментарий к статьям 1110-1185, 1224 Гражданского кодекса Российской Федерации [Evgeny Yu. Petrov in Succession Law: An Itemby-Item Commentary of Articles 1110-1185, 1224 of the Civil Code of the Russian Federation] 149 (E.Yu. Petrov (ed.), Moscow: Statut, 2016).

34 Cf. Comparative Succession Law. Vol. I, supra note 24, at 450. 
The testator shall be entitled to create a will without providing other persons, including a notary, with the chance of familiarising himself with the content thereof (a closed will).

I mention this while discussing wills drawn up in a holographic form because such closed testaments "[s]hall be hand-written and signed by the testator. Failure to observe these rules shall cause the invalidity of the will." Simply put, it could be said that this is a holographic testament that is passed to a notary for safe-keeping. However, such a view would seem to be incorrect, as leaving a handwritten will in the house or passing it to friends for safe-keeping would have no legal effect. In this context, one can argue as to the point of the requirement in Russian law to write the will in full by hand, since if it is handed over to a notary in an envelope, it would be sufficient to merely sign a text typed up on a computer. Moreover, although we are talking here about a specific form of a notarial will (despite the presence of features typical of a holographic will), at a certain moment two witnesses are required and this requirement is mandatory. Part 3 of Article 1126 of the Russian Federation Civil Code requires that:

[The] closed will shall be passed in a sealed envelope by the testator to a notary in the presence of two witnesses who shall put their signatures on the envelope. The envelope signed by the witnesses shall be put into another envelope and sealed in the presence of the notary, who shall enter an annotation on the envelope with information on the testator from whom the notary has accepted the closed will, on the place and date of acceptance thereof, the full names and residential addresses of each of the witnesses in compliance with their personal identity documents. ${ }^{35}$

Perhaps this would be too far-reaching a postulate for Russian legal doctrine and practice, but given the rather stringent requirements regarding identifying the testator and confirming the will has been deposited with a notary, it might even be permitted for the testator to not sign the will stricto sensu should it be concluded from the testament itself that this is his last will, i.e. the testator provided his name at the beginning of the text, etc.

One additional negative consequence arises from this stance of the Russian legislature: in practice, persons who cannot draw up a testament due to an illness or physical disability are not able to use this type of will. Their physical limitation does not, however, necessarily mean that such a person would not be able to type up a testament on a typewriter or computer. In practice, it is not unheard of for people with disabilities who are completely unable to write by hand due to a physical

35 Civil Code of the Russian Federation (Part Three), supra note 12. 
deformity are, nevertheless, able to use a computer (for example, a person who has lost most of the fingers on both hands as the result of a car accident and can sign his will, but who is in no position whatsoever to write out the entire will by hand). When commenting on the provisions of the Russian Civil Code regarding closed testaments, Russian author V. Gavrilov pointed out that the use of a computer and typewriter is excluded. ${ }^{36} \mathrm{In}$ addition, in the context of existing legislation, Russian legal doctrine pertinently emphasises that since there is a requirement to write out the testament by hand, when drawing up a closed testament one cannot use the assistance of a "rukoprikladchik," i.e. a person who signs the testament instead of the testator if the testator cannot personally write their signature at the end of the testament due to an illness or complete illiteracy. The prohibition laid down by part 5 of Article 1126 of the Russian Civil Code is a completely different issue altogether. Russian legislation forbids the drawing up of joint wills of spouses, succession agreements and wills containing decisions regarding setting up trusts in the form of a closed will. Breaching this prohibition nullifies any such contracts and wills. The complexity of the institutions just mentioned is likely the reason why legislators do not allow such wills to be drawn up without professional assistance. A bequeather who is not familiar with the legal system would thus draw up an invalid testament or a testament that leads to misinterpretation. In the case of a closed testament, the notary has only one obligation as to providing professional legal counsel. In accordance with the last sentence of part 3 of Article 1126 of the Russian Federation Civil Code, when

the notary accepts the envelope with the closed will from the testator, the notary shall explain to the testator the content of item 2 of the present article and Article 1149 of the present Code and shall enter a relevant annotation in the second envelope and shall also issue a document to the testator to confirm the acceptance of the closed will.

Article 1149 of the Russian Civil Code contains provisions on the institution of the mandatory part of the will, which limits the freedom of testament to favouring the various relatives and family members of the testator. As a matter of fact, the notary is only obliged to inform the testator that, should the provisions of the drawnup testament infringe the succession rights of the entities set out in the Act, such provisions in the will may be declared void once the testament has entered probate. It should be emphasised that the notary has no right of access to the testament, so this refers merely to providing information on the mandatory part of the will to the testator, who, of course, can still draw up a potentially invalid testament.

36 Гаврилов В.О. Комментарий к разделу V части III ГК РФ «Наследственное право» [Vladimir O. Gavrilov, Commentary on Section V of Part III of the Civil Code of the Russian Federation "Succession Law"] 58 (St. Petersburg: Piter, 2003). 
Chinese law regulates the form of a handwritten will, which in the European legal tradition can be regarded as the classical structure. In accordance with Article 913 of the DIL, the testament shall be handwritten by the testator, signed by him, and the testament shall indicate the day, month and year it was drawn up. The regulation on holographic testaments provided by Article 912 of the DIL is in practice just a transfer to the new inheritance law of the construction used in Article 17 of the Law of Succession of the People's Republic of China of 10 April 1985: ${ }^{37}$

A testator-written will is one made in the testator's own handwriting and signed by him, specifying the date of its making.

Taking into account the rather clear approach of Chinese legislators, who, in accordance with Article 913 of the DIL, do not require witnesses to be present when drawing up a handwritten will, the requirement that the will shall be written by hand by the testator raises no doubts. This serves to identify the bequeather by comparing samples of his handwriting, which is impossible if the testament is printed. It is not known in what direction the case law will develop after the introduction of the new succession law, nor whether a will that is not $100 \%$ written by hand will be valid; however, the law requires the testament to be drawn up in full, that is to say, without any printed or written additions by other persons. An argumentum a contrario can be put forward after bringing together Articles 914 and 915 of the DIL (comprising provisions regarding what happens when the testator is unable to draw up the testament personally by hand and the provisions on a testament in printed form). Considering Article 913 of the DIL, it is impossible to liberally interpret the requirement to draw up a will personally by hand.

Similar conclusions can be drawn regarding the second statutory requirement for Chinese handwritten wills, namely that about signing the testament. Such a requirement seems absolutely necessary for the validity of the will, if at least because of the function of a signature. In Polish legal doctrine, there is a distinction between the two elements of a signature, viz. the material and intellectual ones. The first is understood to be an element that constitutes a personal graphic depiction allowing identification of the testator. The second element makes it possible to conclude that the testator accepts the content of the dispositions and that the document contains the person's final wishes, and not just a draft of a will. ${ }^{38}$ It can be concluded from the first element that not every graphic depiction will be recognised as a signature. For example, one that was not made in person by the testator, or a graphic depiction that does not allow the testator to be identified at all. As regards the second element, most

37 Law of Succession of the People's Republic of China, supra note 11.

38 Elżbieta Skowrońska-Bocian, Forma testamentu w prawie polskim [Form of a Will Under Polish Law] 43 (Warszawa: Wydawnictwa Uniwersytetu Warszawskiego, 1991). 
importantly this concerns the fact that, in a social sense, the person signing a document is expressing his own will, wants it to have some legal or factual effects and accepts the consequences resulting from signing the document. This function of a signature has developed over centuries. According to J. Gwiazdomorski, the main objective of introducing the requirement for the testament to be signed was to provide an external, formal basis for confirming that the testator had completed the act and, when drawing it up, had the intention of bequeathing something. ${ }^{39}$ From a linguistic analysis it can be concluded that, in principle, a signature should "conclude" a testament, turning a testament draft into a valid testament. In various languages "signature" means"signed under the text." What actually falls under the term "signature," however, is a completely different issue. Article 913 of the DIL does not indicate what a signature means. Such a state of affairs, though, should be deemed correct. A signature is such a universal means of confirming declaration of intent that any general definition would be inappropriate. A similar situation also arises in Polish law and in a number of other legal systems that allow for a handwritten will to be drawn up while not specifying what is meant by a signature at the bottom of the testament. According to Polish author S. Wróblewski, a signature on a promissory note should be understood as an array of graphic characters which, according to the rules of the writing system concerned, form an image of what the name sounds like, and which are put on the document via a technique that reflects the individual characteristics of the signatory. ${ }^{40}$ According to Wróblewski, even the use of shorthand cannot be construed as a lack of a signature, which, in turn, could render the document invalid as a promissory note. ${ }^{41}$ According to J. Ignaczewski, a valid signature is not only a signature with the first and last name, or that with only a last name, but also an abbreviated signature which is used by the signatory for signing documents and which is the "emblem" of his signature. ${ }^{42}$ In turn, E. Skowrońska-Bocian argues that

a signature is a distinctive sign of a personal nature, designed to identify the author and customarily adopted by them. ${ }^{43}$

In her opinion, the signature at the bottom of a testament should consist of a full name, but it may also be limited to the last name. In the case of compound surnames,

39 Jan Gwiazdomorski, Podpis na testamencie holograficznym [Signatures on a Holographic Testament], 7-8 Nowe Prawo [New Law] 943, 947 (1962).

40 Stanisław Wróblewski, Prawo wekslowe i czekowe [Promissory Note and Cheque Law] 34 (Kraków: Leon Frommer, 1936).

$41 \quad$ Id. at 35 .

42 Jacek Ignaczewski, Prawo spadkowe: Art. 922-1088 KC: Komentarz [Inheritance Law: Articles 922-1088 of the Civil Code - Commentary] 126 (Warszawa: C.H. Beck, 2004).

43 Skowrońska-Bocian 1991, at 43. 
it is possible to put only one of the surnames, and it is also possible to sign with an alias, if the natural person consistently uses it in legal matters ${ }^{44}$ In practice, China will certainly also face a number of issues identical to those that European legal systems have had to deal with, for example whether it is possible to sign a will with an alias or merely with initials.

On the other hand, the appropriateness of the solution in Chinese legislation regarding how a handwritten will is to be dated may raise doubts. The very fact that Article 913 of the DIL requires a testament to be dated (with the day, month and year) is beyond doubt. Given that there are no exceptions in the Act, this seems to be a mandatory requirement, thus the absence of the date may in casu lead to the invalidity of the will. There seem to be no arguments to show that in every case the absence of the date would not allow the true will of the testator to be properly fulfilled. One may advocate for the introduction into Chinese law of a regulation similar to Article 949 of the Polish Civil Code, i.e. the absence of a date does not nullify a handwritten will should it not raise doubts as to: the capacity of the testator to draw up the will, the content of the will, or to the mutual relationship between several wills. It is difficult to explain why if only one will was drawn up with clear content and with no doubt as to the mental state of the testator, the absence of the date would result in the will being invalid.

Article 914 of the DIL sets out a qualified case for holographic wills. Should the testator not be able to draw up his own testament by hand due to physical limitations, then two witnesses are required to be present when the testament is drawn up. It seems that the presence of these witnesses should be understood as their witnessing the entire process of drawing up the testament, since one witness is to write down and sign the testament, and then the testament is signed by any other witnesses and the testator. It can be concluded from this approach of the Chinese legislature that in order to make use of this form of testament, the testator, who is not able to draw up the entire will by hand, should at least be able to sign the testament. A testator may even be blind, as long as they are capable of signing the testament and have confidence in the witnesses.

The testament must indicate the day, month and year it was drawn up. Such a requirement seems entirely justified, as there may be doubts as to the mental state of the testator, who, by definition, is a person with certain physical limitations, otherwise he would have benefited from an unqualified form of holographic testament. Moreover, there may also be concerns as to the ability of those present, when the will was drawn up, to witness it. Finally, it should be stressed that Chinese law does not require a testator who is unable to draw up a will by hand to be in a life-threatening situation or under special conditions which prevent him from

44 Elżbieta Skowrońska-Bocian, Komentarz do kodeksu cywilnego. Księga czwarta. Spadki [Commentary on the Civil Code. Book Four. Inheritance] 96 ( $6^{\text {th }}$ ed., Warszawa: LexisNexis, 2005). 
using other forms of will. This demonstrates that such a variety of handwritten will is not an ordinary will.

\section{Notarial Wills}

In European legal systems, notarial wills are one of the most common forms of testament. Having analysed particular regulations in force in different European countries, A. Verbeke and Y.-H. Leleu distinguish four types of wills. One of them is the so-called public will, which, in most countries, is drawn up by notaries. ${ }^{45}$ Undoubtedly, testaments drawn up as notarial acts in accordance with Chinese and Russian law must be included in this group. However, despite the prevalence of this form of will, there are fundamental differences between the regulations contained in various legal systems. In addition, even in a single legal system there may be separate forms of notarial will, as was briefly mentioned in the previous section, where Russian notary closed wills were discussed in detail. One must agree that,

Although there are differences in points of detail, the overall procedure for "open" wills in the modern law is largely the same everywhere, and is determined as much by general notarial law as by special rules for wills. ${ }^{46}$

This is also true with regard to Russian and Chinese notarial wills. Polish law, however, is a different case since notarial wills are in fact not regulated by the civil code. In Article 950 of the Polish Civil Code, regulating notarial wills, legislators provided only a brief indication that a testament can be drawn up in the form of a notarial act. In other words, a notarial will should fulfil all the requirements laid down for drawing up a notarial act. Nevertheless, Chinese and Russian law differs on a number of issues, which can be seen at the very first stage of drawing up a will, as is distinguished in European legal doctrine:

First, the testator makes an oral declaration of the will to the notary and two witnesses. ${ }^{47}$

Part 1 of Article 1125 of the Russian Civil Code provides that,

A will attested by a notary shall be signed by the testator or written by a notary [based] on the testator's words.

45 Cf. Towards a European Civil Code 180 (A. Hartkamp et al. (eds.), $2^{\text {nd }}$ ed., The Hague; London; Boston: Kluwer Law International, 1998).

46 Cf. Comparative Succession Law. Vol. I, supra note 24, at 449.

47 Id. 
In other words, it is possible to bring a written text of the will to a notary or to make an oral statement. The same applies to a joint will (for married couples), which may be presented to a notary or written down by a notary from the words of the married couple and in their presence. This approach is in line with the subsequent provision of part 1 of Article 1125 of the Russian Federation Civil Code stating that,

Technical facilities can be used to write or record a will (computer, typewriter, etc.).

One should understand by this that the testator may go to a notary with a printed draft of the will, but also a notary, when drawing up the notarial act, is allowed to use a computer and a printer. In the Russian literature on the subject, it is indicated that most often the testator declares his will to a notary orally, and, in any case, the notary has no right to demand that the testator present a will written beforehand. ${ }^{48}$ In any case:

A will written by a notary [based] on a testator's words shall be read in full by the testator in the presence of the notary before it is signed ... If the testator cannot read the will by himself the notary shall read out the text for him, with a relevant annotation to this effect being entered in the will as including the reasons why the testator could not read the will by himself. [pt. 2 of Art. 1125 of the Russian Federation Civil Code]

In addition, "The will shall be signed by the testator's own hand." Earlier (section 3 above), the institution of a so-called "rukoprikladchik" was mentioned. This arises when the testator himself cannot sign the testament by hand. According to clause 2 of part 3 of Article 1125 of the Russian Civil Code:

If a testator, due to physical disability, grave illness or illiteracy, cannot sign a will by his own hand the will can be signed on his/her behalf on his/her request by another citizen with a notary in attendance. The will shall include the reasons why the testator could not sign the will by himself and also the full name and residential address of the citizen who signed the will on the testator's request, in compliance with the citizen's personal identity document. ${ }^{49}$

From such a statutory template, it is clear that, according to Russian law, one notary attests the will. In Chinese law the situation is different. In accordance with

\footnotetext{
48 Tychinin 2016, at 70.

49 Civil Code of the Russian Federation (Part Three), supra note 12.
} 
Article 918 of the DIL, a will can be attested by a testator in notarial organisations. However, in a notarial organisation no fewer than two notaries are required for notarial attestation to take place. This approach seems to be excessively strict. There is no doubt that the presence of more than one notary will increase safety and ensure that the true will of the testator really is recorded. At the same time, even with the participation of one notary, a notarial will is regarded as the most reliable form of will, and it is rarely contested in court. The absence of a large number of invalidated notarial wills is the best evidence of this. Practically in every legal system, a notary is a professional who can provide a testator with the necessary help in drawing up a testament. Therefore, the requirement of the presence of two notaries would not seem necessary and it only increases the costs of drawing up a will. Nevertheless, the attachment of Chinese legislators to this construct is so strong that Article 918 of the DIL permits that "in exceptional circumstances, a testament may be attested by a single notary in the presence of not less than one witness." ${ }^{150}$ In fact, the witness, so to speak, replaces the presence of a second notary, or his presence can be considered a means of increasing certainty that the last will of the testator is correctly recorded. Again, this seems to constitute unnecessary distrust in notaries and it creates additional difficulties for the testator. The point is that the testator would like to minimise as much as possible the number of people who are present while drawing up the will, but, at the same time, would like to receive professional assistance in drawing up the testament. The presence of a witness will not provide any help and, simultaneously, it will unnecessarily extend the circle of persons with access to the process of drawing up the will. Even though in Russian law a witness (witnesses) may also be present when drawing up a notarial will, this may only take place at the explicit request of the testator. According to part 4 of Article 1125 of the Russian Federation Civil Code:

A witness can be in attendance when a will is drawn up and attested by a notary if the testator so wishes. If a will is drawn up and attested with a witness in attendance it shall be signed by the witness and it shall bear an indication of the full name, surname, middle name and residential address of the witness in compliance with the witness's personal identity document.

The notary has no right himself to call for, or to impose on the testator, the presence of a witness. Of course, should such a witness be invited by the testator, then, "the notary shall warn the witness of the need [to observe] the will nondisclosure clause" (pt. 5 of Art. 1125 of the Russian Federation Civil Code). Such an approach makes it possible to avoid situations where the testator does not wish anyone to be present except the notary, but the law imposes additional persons, such as witnesses, on him.

\footnotetext{
50 Supra note 23.
} 


\section{Printed Wills in Chinese Law}

Unlike Russian law, Chinese law provides for the possibility of drawing up a so-called printed will as a separate form of will. This is a form of home will in the sense that it does not require attestation by an official or notary as a representative of a profession of public trust. Sometimes, such wills are described as "witnessed wills," because their drawing up requires witnesses, as is the case in Chinese law. As a consequence,

Witnessed wills thus occupy some of the middle ground between holograph and notarial wills and, in common law jurisdictions at least, may be treated as doing the work of both. ${ }^{51}$

Article 915 of the DIL states that should the testament be printed, at the place where it is drawn up two witnesses must be present, and each page of such a testament shall be signed by the testator and all the witnesses, and the will shall state the date, month and year it was drawn up. ${ }^{52}$ Since the law fails to state otherwise precisely, such a testament can be printed on a regular printer, thus the original text could have been typed on a computer, but it could also have been typed using (almost unheard of nowadays) a typewriter, etc. The law also fails to specify what precisely the testament is to be printed on, so it can only be argued that it has to be a material which allows for the identification of the signature of the witnesses and testator. It seems that a testament partially written by hand, and partly printed, should be considered a form of printed testament, thus the presence of witnesses is required. Given the absence of a specific requirement, witnesses do not need to be present at the time the testament itself is printed, or to be present at all when, for example, the testator writes his testament on a laptop. However, it seems that the testator should sign each page of the testament in their presence, unless he declares to the witnesses that it is his testament, and then the witnesses should sign the will. It seems that the witnesses should not in any way be responsible for the content of the will, including its validity. Moreover, the witnesses are not obliged to familiarise themselves with the content of the will. It cannot be ruled out that the testator may not wish to disclose any dispositions of property in the event of his death and therefore only declares in general that this is his last wish should he die. In no case, however, must the role of witnesses be to guarantee the accuracy of the content of the testament or to advise the testator. The witnesses are an additional guarantee of the fact that the testament actually comes from the bequeather, and that he was willing to decide upon the dispositions in the event of his death, etc.

\footnotetext{
51 Comparative Succession Law. Vol. I, supra note 24, at 446.

52 Supra note 23.
} 
Should the testament be drawn up in such a way that the text is on both sides of a sheet or several sheets of paper, the testator and witnesses should sign the testament at the bottom of each side. The testator himself decides on the number of witnesses, though at least two are necessary.

Article 919 of the DIL ${ }^{53}$ lists various persons who cannot bear witness to the drawing up of a testament, including a printed will. This list includes:

- a person who is not legally capable or has limited legal capacity, as well as a person who is not legally entitled to be a witness;

- an heir, legatee; in order to avoid any doubt, potential heirs, including persons who hypothetically may claim inheritance based on legal statutes or the will, should be avoided as witnesses. Above all, however, the interdiction concerns those persons named as heirs or legatees in the testament, which they could be the witness of;

- persons who have an interest in an heir or a legatee receiving an inheritance or bequest; such exceptionally inclusive wording actually excludes close relatives and in-laws, since it can always be concluded that a family member may be interested in the enrichment of another family member. At the same time, it is difficult to claim that the presence of even a distant in-law may automatically lead to the nullity of the will. In casu it may be established that such a person could not have had any interest in a distant relative or in-law receiving an inheritance or bequest. It is not known how the case law will develop, but, in theory, a witness should not be a creditor of the potential legatee or heir. A creditor may be interested, as this would make it easier for him to recover a debt from an enriched heir or legatee. It is also worth mentioning that Russian law more precisely regulates the prohibition on family members performing witness duties when drawing up wills. It is stated in part 2 of Article of 1124 of the Civil Code of the Russian Federation that a person who is to benefit from a will or from a bequest in a will, as well as the spouse of such a person, or the children or parents, cannot witness a will. When drawing up a joint will (for a married couple) the spouse cannot be a witness. Of course, similarly to Chinese law, according to Russian law a person without full dispositive capacity, illiterate persons and any person with physical disabilities that do not allow them to understand the essence of the event in full cannot be a witness. Furthermore, neither a notary nor any other person who attests the will can be a witness, nor can any person who fails to possess a sufficient command of the language in which the will is written (except in the case of a closed will), or any party to the succession agreement.

\footnotetext{
53 Supra note 23.
} 
In any event, the civil law of the Russian Federation does not provide for a form of will similar to that of a printed testament in Chinese law. I mentioned earlier that part 1 of Article 1125 of the Russian Federation Civil Code indicates that should a notarial will be drawn up,

Technical facilities can be used to write or record a will (computer, typewriter, etc.). ${ }^{54}$

However, this only applies to the technical side of a notarial testament. In turn, the last sentence of part 1 of Article 1124 of the Russian Civil Code states that

it is not permissible to draw up a testament using electronic or other technical means (second paragraph of point 1 of Article 160 of this Code). ${ }^{55}$

Article 160 of the Russian Federation Civil Code is devoted to forms of written actions in Russian law. The second paragraph of point 1 of Article 160 states that the written form of an act is also respected when the document is drawn up using electronic or other technical means that allow the text of the document to be reproduced unchanged on a tangible medium; furthermore, the requirement for there to be a signature is considered to be fulfilled if any method whatsoever is used so that it is possible to identify precisely the person who expressed his will. Theoretically, this provision could be applied to a will, seeing it as a unilateral act, but the prohibition in part 1 of Article 1124 of the Russian Civil Code explicitly eliminates such a possibility.

\section{Video Testaments and Audio Testaments in Chinese Law}

Chinese law is one of the few legal systems that allows one to draw up a will in the form of a video testament (for purposes of simplification I will use this term, although it also refers to an audio testament). In accordance with Article 916 of the DIL, should a testament be drawn up in the form of an audio or video recording, at the place where such a testament is drawn up the presence of no fewer than two witnesses is required, and the audio or video recording must contain the names or image of the testator and all witnesses, as well as the day, month and year of recording. One must compliment Chinese law on the fact that there is no guidance as to how a video testament can be produced, as the legislator would surely not be able to keep up with technological developments. The use of any technique that allows audio and video to be recorded is permitted. One must agree with $\mathrm{M}$. Załucki that

\footnotetext{
54 Civil Code of the Russian Federation (Part Three), supra note 12.

55 Id.
} 
a video testament should be technologically neutral. For its validity, the video and audio recording of the will-writing process should not depend on how it is recorded. This will also allow this legal concept to be used in the event of further technological changes in audio and video recording. ${ }^{56}$

This exact postulate is fulfilled by Chinese law.

Moreover, it does not matter how the date, for example of the video recording, is indicated. The recording equipment (e.g. video camera) can automatically record with a timestamp, but also either the testator or witness can verbally specify the date, which will be saved in the recording. It would seem that, when making a video recording (not just audio), the law does not require those present to specially identify themselves, if it is clearly visible who the testator is and who the witness is. This approach may make it difficult to later search for the witnesses seen in the recording. It should be specified that both the testator and witnesses should first present their personal data (such as their first name or last name) to enable their identification. It is questionable whether the legislation which regulates the form of any video testament should require the testator to make a statement (using any oral formula) at the beginning of the recording to say that this is his disposition of his property in the event of his death. This would allow one to eliminate, at least in some situations, statements made as a joke, as a test, and those made to give a certain impression yet without wanting to produce subsequent legal effects. In any case, witnesses must be present from the beginning to the end of the process of drawing up the will. The legislation does not explicitly envisage the possibility of making a statement to the witnesses that, on a particular date, the testament has been recorded using a specific medium. Therefore, naturally, the witnesses must be familiar with the content of the will. It should also be emphasised that Chinese law does not specify that the testator drawing up the video testament should read the will orally. Probably it will be rare, but a testator who is unable to speak can record himself writing his last will on a piece of paper and showing it to the camera. On the other hand, video testaments provided for by Chinese law are an appropriate form for people who cannot write or even sign a testament (in such cases the possibility of using the form of a handwritten will or that of a printed one is excluded).

It is also possible to put forth a proposal de lege ferenda that Chinese legislators should probably abandon the form of audio testaments in favour of providing only for video testaments, understood as recordings of images. For a variety of reasons, if only an audio recording is available, it can be difficult to identify the testator and witnesses. For example, if no recording of the testator's voice has survived, or such a recording comes from a different period in the life of the testator, or it has become distorted by technology. In the case of an audio testament there is a greater

56 Załucki 2018, at 238. 
probability that the will was created under the threat or impact of violence. Moreover, such a recording, compared to a video recording, provides fewer opportunities to assess the mental state of the testator at the time of drawing up the will. I am well aware that even a video testament that is of good quality, depicting the testator and witnesses, often cannot serve as proof that, at the time the will was drawn up, the testator was of sound mind. Technological advances might serve as an additional argument for abandoning audio testaments, which, as mentioned earlier, in fact have been a traditional form of will in Chinese law since the late 1980s. At the time the regulation regarding audio testaments was introduced into Chinese law, viz. the year 1985, the practice of recording a "home video" was neither very widespread nor particularly available. I shall not mention the greater problems of archiving video recordings. In other words, technological development has led to a situation in which the average person is more likely to record a video (with sound) than just make an audio recording. It is not even a matter of people's preference for video recording, but just the fact that devices that allow both video and audio to be recorded are becoming more and more common nowadays. In a sense, audio has now become linked with video.

At present, it is impossible to talk about shaping a specific European legal tradition in respect to drawing up video testaments. However, video testaments have been discussed in a number of publications in various languages, even though they are not regulated in most countries, and, considering the closed list of forms of wills (a list that cannot be extended easily), such a situation is equivalent to a ban on drawing up such testaments. There are often quite detailed proposals for introducing this form of will in particular countries. Very frequently, such proposals differ significantly from the solutions adopted in Chinese law. This should not be surprising, since these are merely proposals de lege ferenda that do not directly refer to Chinese law. Nor does it make sense to examine proposals primarily regarding local law, for example those concerning the possible inclusion of provisions on video testaments among the existing forms of wills. However, it is worth noting that, in the context of European legal doctrine, video testaments are often perceived to be a more modern alternative to handwritten testaments and, consequently, they would constitute a form of "home" will. According to M. Załucki,

any declaration of will made by the testator should not be made in the presence of witnesses. The personal nature of the will-writing activities, as well as the possible distortions of the last will that arise from this context, advocate in favour of such a solution. ${ }^{57}$

When developing his idea, the author stated that

57 Załucki 2018, at 238. 
the presence of witnesses would not significantly increase the security of the legal transaction, and in turn it could have a negative impact on the bequester themselves. ${ }^{58}$

There is no doubt that Chinese legislators chose a different path. The presence of witnesses does not contribute to creating a more intimate atmosphere at the time of drawing up the testament; moreover, there might be a leak of information about the content of the will, which may have disastrous consequences for the life of the testator. At the same time, the argument that the presence of witnesses may not be conducive to the safety of the legal transaction may be disputed. The problem with a handwritten testament results from the fact that it can be destroyed by persons who are hostile to the content of the will, and the likelihood of detecting such wrongdoing is negligible. In many cases, those around a recently deceased testator are not aware of the fact that a handwritten will has been drawn up. The same can happen in the case of a video testament, which can be destroyed as easily as a handwritten one. Chinese legislators made an effort to create an instrument that is cheaper and easier to implement, but, at the same time, ensured minimal safety and security for it. Witnesses are also present, to some extent, in order to increase the import of the situation. The expansion of recording technologies may lead to "widespread" use of these methods, and they are no longer as unusual as they were twenty years ago. This accessibility and universality can result in a lack of understanding regarding the legal implications of leaving behind a recording. A testator who calls his witnesses is certainly aware that without their participation the testament will be invalid, something which increases his awareness of the consequences of his decisions. Paradoxically, someone who arrives at a notary's office or who makes a declaration of will in the presence of witnesses is not participating in an everyday activity (such as using a smartphone) and, for this reason, the person is more serious and thoughtful about how he draws up his testament, and thus is not acting on a whim.

The desire in modern literature on the subject of inheritance law to increase the potential attractiveness and availability of new forms of wills, including video testaments, through ever more liberalisation of the enshrined requirements, would not seem to be felicitous, as it inevitably leads to distortion of the bequeather's will and to decreasing certainty as to the authenticity of the declared will. It is often forgotten that formal requirements and restrictions are not intended to complicate the life of the testator, but to make sure that the genuine will of the testator is preserved (and not a distorted version). The mere fact that new techniques enter into more common use should not automatically preordain that a testament should be drawn up in this way without any additional requirements.

58 Załucki 2018, at 242. 
At the moment, Russian law does not allow a video testament to be drawn up in any situation. As I mentioned earlier, the last sentence of part 1 of Article 1124 of the Russian Civil Code states that

it is not permissible to draw up a testament using electronic or other technical means (second paragraph of point 1 of Article 160 of this Code)..$^{59}$

However, it must be mentioned that according to part 5.1 of Article 1125 of the Civil Code of the Russian Federation, when attesting a joint testament drawn up for a married couple (and only a notary is eligible to attest such a document), the notary is obliged to make a video recording of the joint testament being drawn up for the couple, unless the couple object to it. Therefore, this is not a video testament sensu stricte, only the obligation imposed by the law on the notary to record the process of the couple declaring their will. Most importantly, without affecting the validity of the will, the married couple are able to effectively prevent this recording of their will being drawn up. Therefore, this is not an obligatory element of this form of will.

\section{In Lieu of Conclusions}

This study cannot be considered an exhaustive analysis of all the issues related to the form of wills in Russian and Chinese law. I have limited myself to examining the main forms of ordinary wills, without addressing the issue of special wills or specific forms of wills, such as, for instance, the disposal of bank deposits in the event of death, the possibility of a consul attesting a will, or aircraft, military, or joint wills (of married couples). Despite the amount of detail contained in the issue of the form of a will, as has been examined in the two different legal systems, a number of general conclusions can be drawn. Chinese law concentrates a lot on various forms of will, including those related to new technologies. Although attempts are being made to introduce certain precautionary measures, Chinese law provides for an extremely wide range of forms of wills, which probably helps to avoid situations of intestate succession, but it also increases the risk of distorting the will of the testator. Some constructs are so innovative that one is still waiting for legal practice to catch up (not to mention case law). Nowadays, Chinese regulations no longer seem to be influenced by the overpowering legacy of Soviet law. For instance, some of its forms of ordinary wills were never known to Soviet law.

Russian law continues to ensure the dominant position of the notarial testament, but it is impossible not to notice the search for, and creation of, additional opportunities for testators within this form of will. The role of the notary varies considerably depending on the type of will, although it can be formally stated that both the

59 Civil Code of the Russian Federation (Part Three), supra note 12. 
ordinary notarial will and the closed testament are equally forms of a notarial will. Therefore, Russian legislators have been more cautious, prioritising the security of the legal process as well as retention of the true will of the testator. The number of invalid wills must be relatively small. Obviously, in such a rigid system, there is a greater risk that a testator will not draw up a will and that the succession will take place on the basis of succession as set out in law. Thus Russian legislators, while being aware of the need to modernise the law (particularly regulations providing for forms of wills), have done so in a different way to that chosen by Chinese legislators.

\section{Acknowledgments}

I would like to extend special thanks to Evgeny Erbakhaev, LL.M., who afforded me the invaluable service of helping me translate Chinese legislation into the Russian language. This greatly helped me comprehend the pertinent issues in Chinese inheritance law. I would also like to express my gratitude to Professor Wang Zhihua for his gracious and illuminating clarifications concerning Chinese inheritance law.

\section{References}

Comparative Succession Law. Vol. I: Testamentary Formalities (K.G.C. Reid et al. (eds.), Oxford: Oxford University Press, 2011). https://doi.org/10.1093/acprof:oso/978019 9696802.001.0001

Ignaczewski J. Prawo spadkowe: Art. 922-1088 KC: Komentarz [Inheritance Law: Articles 922-1088 of the Civil Code - Commentary] (Warszawa: C.H. Beck, 2004).

Kuryłowicz M. Testamentum holographum, 13(10) Rejent [Notary] 119 (2003).

Łągiewska M. Charakterystyka chińskiego prawa cywilnego - wybrane aspekty [Characteristics of Chinese Civil Law: Selected Aspects], 12 Gdańskie Studia Azji Wschodniej [Gdansk Journal of East Asian Studies] 86 (2017).

Lebedowicz G. et al. Zarys chińskiego prawa cywilnego w dobie kodyfikacji [An Overview of Chinese Civil Law in the Era of Codification] (Toruń: Adam Marszałek, 2019).

Towards a European Civil Code (A. Hartkamp et al. (eds.), $2^{\text {nd }}$ ed., The Hague; London; Boston: Kluwer Law International, 1998).

Wróblewski S. Prawo wekslowe i czekowe [Promissory Note and Cheque Law] (Kraków: Leon Frommer, 1936).

\section{Information about the author}

Jarosław Turłukowski (Warsaw, Poland) - Assistant Professor of Civil and Commercial Law, University of Warsaw (26/28 Krakowskie Przedmieście St., Warsaw, 00-927, Poland; e-mail: j.turlukowski@wpia.uw.edu.pl). 